\title{
Taking risks seriously
}

\section{John Launer}

I was working recently with a group of Danish doctors on a course where they had a chance to talk about some of their most difficult patients: complex cases, challenging ones, people who had worn them down over the years by consulting very often but never getting any better. One theme came up again and again in their stories. It was the theme of risk. The doctors on the course didn't mean the kind of risk we spend so much time thinking about in medicine these days, like blood pressure, smoking or obesity. What they had in mind was the way doctors sometimes to take emotional risks with patients-for example, by cracking a joke, being intentionally provocative, and even losing their temper. Time and again, they told stories of how they had turned the corner with difficult patients not by being boringly predictable or scientifically clever, but by showing their own emotions. The stories they told weren't about being punitive or moralistic. They were all about being authentic, being themselves.

Listening to them, I was struck by a certain paradox. I began to wonder if we have become preoccupied in medicine with preventing health risks in patients, while forgetting the art of the taking emotional risks ourselves. To some extent this may simply be due to technology: we often spend more time nowadays looking at screens and writing requests for blood tests than we do talking with patients. But I suspect it may be part of a change in our attitudes too. We are more scared than we used to be of lawyers, managers, commissioners and regulators, and so we have become emotionally risk averse. In the UK, I fear that the kind of courageous medicine my Danish colleagues were describing is becoming a thing of the past.

\section{SHOCKING CONSULTATION}

After hearing their own stories, I told the Danes about the most shocking-and possibly the most educational-consultation I have ever observed myself. It happened many years ago, when I was watching my own GP trainer

Correspondence to Dr John Launer, London Deanery, London Department of Postgraduate Medical Education, Stewart House, 32 Russell Square, London WC1B 5DN, UK; jlauner@londondeanery.ac.uk at work in his surgery. He had already been there for many years, and he knew most of his patients extremely well. They also knew him as a charismatic man who looked them straight in the eye, laughed and cried with them without much inhibition, and almost invariably told them what he thought. The third or fourth patient of the day was a woman of about his own age, who greeted him by his first name as many of his patients did. She sat down and in a rather humdrum way she said she had a sore throat. Quick as a flash, my trainer asked her: "And why the $\mathrm{f}^{* * *}$ have you really come?" I thought she would hit him, or walk straight out of the room to phone her solicitor or the General Medical Council. But she didn't. She answered the question instead-like a reflex, and without a moment to pause. Her real reason had nothing at all to do with a sore throat. Her doctor knew her well enough to realise this, and was brave enough to shock her into telling him what was really on her mind.

I have thought about this encounter many times over the years. What my trainer did on that occasion was outrageous, but it was also spontaneous, intuitive, and above all effective. I don't know whether he used the micro-second before he spoke to carry out a mental calculation about the risks he was taking and the likely benefits. I suspect not. However, I am certain that he was working from a fundamental belief that what mattered most in medicine was doing whatever was going to help the patient most at that particular moment, and not any rules, guidelines, received wisdom, or any of the 'oughts' that generally dominate our conduct as doctors.

\section{TRANSFORMATIONAL MOMENTS}

I have never been able to reproduce that precise example of risk taking in a consultation, but it would be wrong even to try. Each of these transformational moments is by definition a one-off, suited only for that particular doctor and patient, and that consultation. But it is one of many incidents that has convinced me that the best medicine is often subversive. It doesn't always work through doing what is right and proper according to textbooks and governments. Sometimes it works instead by throwing all these things out of the window. It can even mean doing the diametric opposite of what you are 'meant' to do. (One doctor I know, for example, recently told a patient going through a family crisis that his drug habit probably reduced his anxiety and now was not the right time to try and give it up.)

This is an easy point to make, and most doctors with any experience would agree with it. The question is: how do we teach it? You clearly cannot go around telling medical students and junior doctors that it is fine to lose your temper, use four letter words in the consulting room or advise patients to carry on taking addictive drugs. We need to impart the spirit of these experiences instead. The best way of doing this is probably by modelling it, and by demonstrating that if you take the right risks the earth won't open to swallow you up, and you won't be struck off either. But there are some sound general principles underlying good risk taking, and it wouldn't do any harm to teach these far more than we do.

\section{UNIQUE CONVERSATIONS}

One principle is that evidence and medical guidelines may apply to groups of people, but they don't necessarily apply to individuals. The only place where evidence and individuals ever converge is through conversations, and every conversation is unique. ${ }^{1}$ Medical conversations can be dull and repetitive but they don't need to be. They can also be creative, imaginative and enjoyable-and they probably need to be if they are to make any impact on patients. Another principle worth teaching is that the contexts surrounding any medical conversation-including science, law, social rules and conventions-can influence an encounter, but they cannot substitute for it. ${ }^{2}$ Codes of conduct are by their nature abstract and general, and they can never tell you what to do in every conceivable eventuality. If your heart tells you to break the relevant code, you may sometimes need to follow your heart. Indeed, it may be more ethical to do so than just to follow orders, as we know from innumerable examples of courage and risk taking in the past.

Perhaps the most important principle behind courageous and effective risk taking is that evidence and guidelines cannot be allowed to float around in a moral vacuum. In order to have meaning, they need to be embedded in a relationship, and grounded in values. ${ }^{3}$ Taking emotional risks with patients, however scary, may be the best way of 
showing that relationships and values still matter in medicine.

\section{Competing interests None.}

Provenance and peer review Commissioned; not externally peer reviewed.
Postgrad Med J 2010;86:511-512. doi:10.1136/pgmj.2010.104398

\section{REFERENCES}

1. Charon $\mathbf{R}$, Wyer $\mathbf{P}$. for the NEBM working group. Narrative evidence based medicine. Lancet 2008;371:296-87.
2. Tilly C. Why? What happens when people give reasons... and why. Princeton: Princeton University Press, 2006

3. Frankel R. Relationship-centered care and the patient-physician relationship. J Gen Int Med 2004:19:1163-5

\section{Correction}

An article published in the June 2010 issue of the journal (Wood AJ, Douglas RG. Pathogenesis and treatment of chronic rhinosinusitis. Postgrad Med J 2010;86:359-64) contained errors within Box 1 "Suggested medical regimen". In the third and fourth bullet points, "3 weeks" was incorrectly written as "3 months". In the fourth bullet point, "once" was incorrectly written as "one". The bullet points should read:

- Roxithromycin $300 \mathrm{mg}$ or doxycycline $200 \mathrm{mg}$ orally once daily for 3 weeks

- Prednisone $0.5 \mathrm{mg} / \mathrm{kg}$ orally once daily tapering over 3 weeks

Postgrad Med J 2010;86:512. doi:10.1136/pgmj.2009.094813corr1 